"Innovation imperatives of global financial innovation and development of their matrix models"

\begin{tabular}{|c|c|}
\hline AUTHORS & $\begin{array}{l}\text { Nataliia Savchuk (iD } \\
\text { R } \\
\text { Tetiana Bludova (iD) } \\
\mathbb{R} \\
\text { Dmytro Leonov (D) } \\
\mathbb{R} \\
\text { Olena Murashko (i) } \\
\mathbb{R} \\
\text { Nataliia Shelud'ko (i) } \\
\mathbb{R}\end{array}$ \\
\hline ARTICLE INFO & $\begin{array}{l}\text { Nataliia Savchuk, Tetiana Bludova, Dmytro Leonov, Olena Murashko and } \\
\text { Nataliia Shelud'ko (2021). Innovation imperatives of global financial innovation } \\
\text { and development of their matrix models. Investment Management and Financial } \\
\text { Innovations, 18(3), 312-326. doi:10.21511/imfi.18(3).2021.26 }\end{array}$ \\
\hline DOI & http://dx.doi.org/10.21511/imfi.18(3).2021.26 \\
\hline RELEASED ON & Monday, 13 September 2021 \\
\hline RECEIVED ON & Tuesday, 27 July 2021 \\
\hline ACCEPTED ON & Friday, 10 September 2021 \\
\hline LICENSE & $\begin{array}{l}(c) E Y \quad B \\
\text { This work is licensed under a Creative Commons Attribution } 4.0 \text { International } \\
\text { License }\end{array}$ \\
\hline JOURNAL & "Investment Management and Financial Innovations" \\
\hline ISSN PRINT & $1810-4967$ \\
\hline ISSN ONLINE & $1812-9358$ \\
\hline PUBLISHER & LLC “Consulting Publishing Company "Business Perspectives" \\
\hline FOUNDER & LLC "Consulting Publishing Company "Business Perspectives" \\
\hline
\end{tabular}

NUMBER OF REFERENCES

35

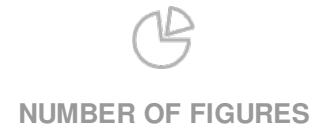

7
NUMBER OF TABLES

1

(C) The author(s) 2021. This publication is an open access article. 


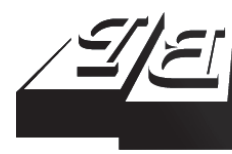

\section{BUSINESS PERSPECTIVES}

0

LLC "CPC "Business Perspectives" Hryhorii Skovoroda lane, 10, Sumy, 40022, Ukraine www.businessperspectives.org
Received on: $27^{\text {th }}$ of July, 2021 Accepted on: $10^{\text {th }}$ of September, 2021 Published on: $13^{\text {th }}$ of September, 2021

(C) Nataliia Savchuk, Tetiana Bludova, Dmytro Leonov, Olena Murashko, Nataliia Shelud'ko, 2021

Nataliia Savchuk, Dr in Economics, Prof., Department of International Finance, Faculty of International Economics and Management, Kyiv National Economic University named after Vadym Hetman, Ukraine.

Tetiana Bludova, Dr in Economics, Prof., Advanced Mathematics Department, Marketing Faculty, Kyiv National Economic University named after Vadym Hetman, Ukraine. (Corresponding author)

Dmytro Leonov, Ph.D. in Economics, Prof., Ukrainian Stock Market Development Institute, Kyiv National Economic University named after Vadym Hetman, Ukraine.

Olena Murashko, Ph.D. in Economics, Prof., Department of Banking and Insurance, Faculty of Finance, Kyiv National Economic University named after Vadym Hetman, Ukraine.

Nataliia Shelud'ko, Dr in Economics, Prof., Head of the Department of Monetary Relations, State Institution "Institute of Economics and Forecasting of NAS of Ukraine, Ukraine.

This is an Open Access article, distributed under the terms of the Creative Commons Attribution 4.0 International license, which permits unrestricted re-use, distribution, and reproduction in any medium, provided the original work is properly cited.

Conflict of interest statement: Author(s) reported no conflict of interest

Nataliia Savchuk (Ukraine), Tetiana Bludova (Ukraine), Dmytro Leonov (Ukraine), Olena Murashko (Ukraine), Nataliia Shelud'ko (Ukraine)

\title{
INNOVATION IMPERATIVES OF GLOBAL FINANCIAL INNOVATION AND DEVELOPMENT OF THEIR MATRIX MODELS
}

\begin{abstract}
The global financial market is undergoing transformational changes under the growing influence of innovative factors. Such changes are due, in particular, to the concentration and scaling up and diversification of the structure of financial services, the renewal of the financial sector on the basis of FinTech operations and blockchain technologies. This requires taking into account the impact of innovation factors on the transformation of the financial market in the dimension of FinTech. The study aims to identify the imperatives of global financial innovation and show ways to develop innovative models in the interpretation of S-curves for next-generation products using new technologies when key technologies on the previous S-curve become obsolete. Also, the matrix of financial innovations is presented and the synergy of its innovation models is proved.

The results of the study are to prove that each of the presented models is not independent, it evolves and develops itself, as well as affects other models. This made it possible to identify prognostic pathways for the development of innovative models in their synergy in the form of two-ring motion. Thus, the study emphasizes the need for further research aimed at developing innovative models that will determine strategic decisions in the formation of innovation imperatives.
\end{abstract}

\section{Keywords}

JEL Classification

\section{INTRODUCTION}

Financial innovation is related to scientific and technological development, and the number of digital banks is growing, due to the development of FinTech. For decades, the financial industry has made extensive use of information and communication technologies in all its internal processes. With the advent of the Internet, information and communication technologies have allowed banks to offer their services on the Internet to customers from both fixed and mobile devices. In 2018, 51\% of adult Europeans used Internet banking, which is 2 times more than in 2007 (25\%), and in 2018 there are significant differences in age, country, and level of education of users. Today, FinTech is driven not only by the growing spread of innovative IT solutions and the emergence of non-banking companies offering targeted financial services but also by changes in the behavior of banking customers regarding online banking and interbank relations, as well as the spread of mobile devices and digital financial services. Thus, clients gain access to financial information. Given the importance of core business services in banking, FinTech's innovative banking solutions enable a range of new digital services in financial information areas such as planning and consulting, payments, investments, financing, and interprocess support. Based on the evolution of financial technology, the term FinTech means all programs that use analog and primarily digi- 
tal IT to provide financial solutions. It includes a wide range of innovative ideas and new business models using digital technologies.

It is believed that FinTech has a huge potential to improve financial involvement in defining the imperatives of financial innovation. FinTech services can provide wider access to financial services for individuals, small and medium-sized enterprises, especially in the area of loans and payments. According to Crunchbase (n.d.), there are more than 3,850 FinTech service providers worldwide. The EU ranks second (more than 1,000 FinTech companies) in the number of service providers after the US. In terms of investment, the United States ranks $1^{\text {st }}$ (\$29 billion in total investment), China $-2^{\text {nd }}$, the United Kingdom $-3^{\text {rd }}$, India $-4^{\text {th }}$, the EU ( $\$ 3.6$ billion $)-5^{\text {th }}$.

The global banking sector is becoming more strategically oriented and technologically advanced to respond to consumer expectations while trying to protect market share from a growing number of competitors. Banks and credit unions have made greater use of data, analytics, and digitization processes. Much attention is paid to the digitization of key business processes and the revaluation of organizational structures, which illustrates the growing desire to become a "digital bank". Organizations are innovating in the areas of targeting, expanding services, changing delivery channels, providing advisory advice, integrating payments, and using blockchain technology.

As part of these mega-trends, banks will also experiment with new mobile applications and voice gadgets to improve both delivery and contextual personalization. Ultimately, the consumer will be the center of attention. As technology advances, the banking sector will continue to increase its investment in innovation and digital improvement.

It should be noted that financial innovations coexist with technological innovations and provide a mechanism for financing innovative technological projects when traditional sources of funds are not available due to high investment risk. At the same time, technological progress increases the complexity of business processes and new types of risks, which encourages the financial system to change innovatively. It is often emphasized that financial innovations are designed to find a more effective way to redistribute risk among market participants. Today, many factors are influencing the activity of financial institutions to create and implement financial innovations, including globalization and increased variability of market parameters, deregulation, and liberalization of capital flows in the dynamic development of the interconnection of new technologies. Other factors influencing the innovation potential of financial institutions include intense competition among financial institutions, the search for new sources of income, and the growing importance of the risk management process.

Therefore, taking into account the above factors, the development of new innovative models and ways of their development is relevant.

\section{LITERATURE REVIEW}

To determine the innovation imperatives of global financial innovation, the evolution of financial technologies and the financial services system are analyzed. Capgemini (2017) and Stöckli et al. (2018) presented the characteristics and defining criteria for the development of the financial services system in the evolution of the financial services system.
The origins of FinTech have been linked to the spread of the Internet since the 1990s, as noted by Lee and Shin (2018). Also, Arner et al. (2015) recognized the development of financial technology in the mid-nineteenth century. The historical perspective emerges with the advent of financial institutions, as noted by Bouwman et al. (2005), Lee and Shin (2018), Dhar and Stein (2017), and Němcová and Dvořák (2013). Gomber et al. (2018) emphasized that with the creation of digital infor- 
mation and communication technologies, digital financial technologies began to be developed, including electronic transactions between financial companies, financial market participants, and clients from all over the world.

Bettinger (1972) explained that FinTech is an abbreviation that stands for financial technology, which combines banking experience with modern scientific methods of management and computer. Pousttchi and Dehnert (2018) also singled out the FinTech industry as a union of financial services and information technology. Gulamhuseinwala et al. (2015) believed that FinTech is computer programs and other technologies to which they are accustomed that create support or inclusion of banking and financial services. FinTech is one of the fastest-growing areas for venture capital. Stan (2018) notes that FinTech is not limited to specific sectors (e.g. financing) or individual business models (P2P, microcredit, blockchain), it covers the full range of services and products traditionally provided by the industry financial services. Mcwaters (2015) emphasizes that FinTech is a dynamic segment at the crossroads of the financial services and technology sectors, where technology-oriented startups and new market entrants are introducing innovative products and services provided by the traditional financial services industry. There is an opinion that FinTech is a violation of the process and transformation of services for technological innovation "digital financing" or "electronic financing", as seen by Gomber et al. (2017).

Bons et al. (2012) and Marjanovic and Murthy (2016) believed that in the banking sector, technology has created a value that has evolved in four clusters (financial services, channels, interbank service providers, customers).

The degree of vertical integration in the banking sector is high, although IT has increased external processes, and also activities. Interesting is the opinion of Arner et al. (2015): benefits for online banking may outweigh the risks. Gellrich et al. (2005) emphasized that 859 European banks decreased by only $5 \%$. The vertical integration rate decreased from $82.2 \%$ (1995) to $77.2 \%$ (2005). This is characterized in turn by a further reduction in domestic production, but an increase in outsourcing, specialization, and diversification. On the other hand, the number of banks has decreased in the digital phase, and the number of employees has increased.

It should be noted that during the period 1980-2009, banks were reduced from 37,090 to 15,801 (USA); from 3,006 to 1,774 (Germany). At the same time, the workforce increased from 2,019,341 to 2,302,628 (USA); from 495,700 to 633,550 (Germany), as studied by Michalopoulos et al. (2009).

It should be noted that in Europe, retail banks have digitized 20 to $40 \%$ of their processes; $90 \%$ of Eurobanks invest less than $0.5 \%$ of their total spending on digital technologies (CBInsights, 2018). For example, Gopalan et al. (2012) concluded that in the world as a whole, the banking sector spends an average of $4.7-9.4 \%$ of operating income on IT, insurance companies $-3.3 \%$, and airlines $-2.6 \%$.

The average percentage of digitally active consumers who use FinTech services in 2018 was 37\%. Among European countries, the highest share of FinTech users is in the UK (42\%), Spain (39\%), and Germany (37\%), which is higher than the world average. In total, the percentage of users related to FinTech services are distributed in different areas as follows: payments and transfers (50\%), insurance (24\%), savings and investments (20\%), financial planning (10\%), borrowing ( $10 \%)$ (Gomber et al., 2018).

To generalize the theoretical and methodological approaches, it is necessary to outline innovative trends such as the introduction of practices in the field of startups in the banking industry. Capgemini (2017) notes that FinTech startups are clever piranhas that focus on a small part of the bank's business model to attack. Gimpel et al. (2018) believe that understanding FinTech startups implies a taxonomy of consumer-oriented service offerings.

The use of multilateral online platforms to provide FinTech services implies that the first definition of the relevant market can not be based on traditional models, and secondly, the generation of network effects resulting from the combination of platform dynamics and perception and user behavior. On the other hand, FinTech platforms are not as regulated as financial trading platforms, and therefore the risks arising from network effects can be assessed as com- 
petition (CBInsights, 2018; Stöckli et al., 2018). Signs of competition in FinTech are presented in Table 1.

Table 1. Signs of competition in FinTech

Source: Authors' elaboration.

\begin{tabular}{|c|c|}
\hline Categories & Competition issues \\
\hline Banking & $\begin{array}{l}\text { Lack of clear regulatory standards. Banking } \\
\text { platform markets do not have a high intensity } \\
\text { of use }\end{array}$ \\
\hline $\begin{array}{l}\text { Payment } \\
\text { services }\end{array}$ & $\begin{array}{l}\text { Include access to critical assets such as data } \\
\text { and mobile near communications (NFC), as } \\
\text { well as participation in exceptional behavior } \\
\text { towards competitors }\end{array}$ \\
\hline & $\begin{array}{l}\text { The digital currency market is characterized } \\
\text { by competition between currencies (inter- } \\
\text { cryptocurrency market) and competition } \\
\text { between exchanges (intra-cryptocurrency } \\
\text { market) }\end{array}$ \\
\hline $\begin{array}{l}\text { Digital } \\
\text { currencies }\end{array}$ & $\begin{array}{l}\text { One of the factors is the presence of network } \\
\text { effects. Another factor is standardization } \\
\text { distributed book technology (DLT) and } \\
\text { other technical protocols. Private or public } \\
\text { consortium agreements on technical standards } \\
\text { may affect market entry or have an impact on } \\
\text { current costs }\end{array}$ \\
\hline $\begin{array}{l}\text { Wealth } \\
\text { and asset } \\
\text { management }\end{array}$ & $\begin{array}{l}\text { Potential competition challenges in this area } \\
\text { include different payment policies for service } \\
\text { providers, blurring of boundaries between } \\
\text { different types of services (information, } \\
\text { advisory, management), and the consequences } \\
\text { of using algorithms. On the one hand, there } \\
\text { are pro-competitive effects, such as increased } \\
\text { transparency on variable prices and quality, as } \\
\text { well as on more efficient product and service } \\
\text { development. On the other hand, there are } \\
\text { also risks to competition, such as the potential } \\
\text { role of algorithms that facilitate coordination } \\
\text { and conspiracy (algorithmic conspiracy) }\end{array}$ \\
\hline $\begin{array}{l}\text { Competition } \\
\text { issues in the } \\
\text { field (FinTech) }\end{array}$ & $\begin{array}{l}\text { Competition issues related to digital personal } \\
\text { finance management (PFM) services arise } \\
\text { mainly in the area of access to customer data }\end{array}$ \\
\hline Insurance & $\begin{array}{l}\text { Access to customer data and the impact of } \\
\text { algorithms on pricing strategies are the main } \\
\text { factors that can lead to anti-competitive } \\
\text { practices }\end{array}$ \\
\hline $\begin{array}{l}\text { Standardization } \\
\text { of private }\end{array}$ & $\begin{array}{l}\text { Blockchains can also create barriers to } \\
\text { entry if there is a lack of transparency in the } \\
\text { standardization process }\end{array}$ \\
\hline \multirow{3}{*}{$\begin{array}{l}\text { Inclusion of } \\
\text { technology and } \\
\text { infrastructure }\end{array}$} & $\begin{array}{l}\text { There are no special competition problems in } \\
\text { technologies such as DLT, Artificial Intelligence } \\
\text { (AI), and Data Analytics, except for general } \\
\text { ones (standardization, network effects, data } \\
\text { access) }\end{array}$ \\
\hline & $\begin{array}{l}\text { There are some specific niches of cybersecurity } \\
\text { technologies where there are market } \\
\text { concentration and possible competition } \\
\text { problems }\end{array}$ \\
\hline & $\begin{array}{l}\text { For example, the market for modern cloud } \\
\text { services is dominated by a small number of } \\
\text { large technology companies and, in addition, } \\
\text { barriers to access for new entrants to this } \\
\text { market are huge }\end{array}$ \\
\hline
\end{tabular}

1.1. Deposits: demand deposits; savings accounts; time deposits; call deposits.

1.2. Lending and equity: P2P consumer lending; $\mathrm{P} 2 \mathrm{P}$ business lending; trading in invoices based on equity; crowdfunding (real government crowdfunding; P2P property lending; balance sheet business; donation-based lending; debt-based securities); consumer lending (mini-bonds; profit sharing; balance sheet ownership).

Bank for International Settlements (2018) and Stöckli et al. (2018) highlighted payments, transfers, and Forex: mobile wallets; mobile P2P payments; currency and money transfers; real-time payments. Vlastelica (2017) and Young (2016) also define digital currencies: cryptocurrency wallets, payments, exchange and trade, data and their meanings.

Pousttchi and Dehnert (2018) and Dhar and Stein (2017) pay attention to asset and liability management: management; website comparison; the financial aggregate of the platform; Robo-Advisors; social trade and investment platforms, as well as other innovative business models; algorithmic trade. Asset and liability management includes those services aimed at helping customers to optimize the return on their assets. They usually combine financial and investment advice, as well as other services such as tax advice or pension planning. FinTech services in this field are focused on providing automated advisory (robo-consultants) and automated bidding, as well as the inclusion of technology and infrastructure: distributed book; technologies; data analytics; Artificial Intelligence; cybersecurity; extended services from the use of cloud infrastructures. This category includes technologies and infrastructure that enable the provision of FinTech and InsurTech services.

Davies et al. (2016), Ehrenfeld (2017), and Goodale (2012) described the level of change in global transformations in the financial sector. In the economic literature, there are five known stages of business transformation caused by IT. 
Schwab and Guibaud (2016) and Ehrenfeld (2017) investigated the levels of financial transformation that characterize FinTech innovation, which takes into account external, network, and internal organizations. Bons et al. (2012) determined that at the level of internal organization FinTech includes a change of business orientation from internal business processes to customer orientation. Shim and Shin (2016) investigated that at the level of business networks and enterprises have become more closely associated with specialized external partners, and competition is usually more intense at lower margins.

For example, technically crowdfunding can compete with traditional corporate bonds and venture capital funds, as Wilson and Testoni (2014) pointed out. Its rapid expansion into equity and lending segments was based on regulatory exceptions in individual jurisdictions, which allowed fundraising firms not to issue up to a certain maximum amount of funding. If other regulatory requirements apply to the standard package, the attractiveness of crowdfunding and other financial services based on peer-to-peer lending platforms may decrease (Hornuf \& Schwienbacher, 2016).

In addition to the traditional world of financial services, as noted by Davies et al. (2016), FinTech's competitive environment now includes new startups and bystanders who have different corporate cultures, different from traditional financial services firms, which are described by Gomber et al. (2018). Thus, the widespread use of digital infrastructures allows for cost-effective operations and the transition to non-cash.

Mcwaters (2015), Gomber et al. (2018), and Schwab and Guibaud (2016) considered the innovation imperatives of global financial innovation in terms of FinTech components: InsurTec, RegTech, BankTech, as a set of insurance, regulatory, and technologically innovative components. InsurTech directions are presented by Schwab and Guibaud (2016) and Stöckli et al. (2018); RegTech by Gomber et al. (2018), who gave the following definition: "RegTech solutions are aimed at facilitating compliance with regulatory requirements and replacing manual labor in standard regulatory processes". Bons et al. (2012), Stöckli et al. (2018), and Davies et al. (2016) investigated BankTech.
It is emphasized that during the impact of financial innovations on the financial system, changes in its efficiency and stability are possible, so the question of their stability arises. The sustainability of financial innovations is not only determined by reducing the degree of risk and transaction value while minimizing tax payments, but also by strengthening the functions of the financial system. As for technological innovations, they occur when technological development is generated regardless of the specific needs of the financial market and is distributed in a particular sector, thus combining hidden demand. This technological development may be generated by internally innovative companies or may occur in another way. Then financial innovation companies realize the potential of the technology and include it in their products and services. The model of the innovation process is the S-curve, which shows that when financial technology appears, its productivity is usually quite low to reach a certain degree of maturity. Thus, in the process of implementing a useful innovation function is universalization to provide more useful functions and specialization for better implementation of basic functions. From this moment, the productivity of the innovation function begins to grow. The process of intensification of useful innovative functions is started under the condition of the introduction of auxiliary functions (control, diagnostics) with considerable speed. Thus, the most modern innovative functions are created until the technological limit is reached, i.e. the level of financial products, which cannot be overcome due to technological limitations. At this logistical stage, after reaching the limit, financial companies that want to improve their product must make innovative decisions. Therefore, the urgent problem is to consider the innovative prospects of global financial innovation, creating a matrix model of transformation of financial innovation and its interpretation.

\section{RESULTS}

It is necessary to consider the innovative prospects of global financial innovation (Figure 1).

New innovative phenomena can be characterized as follows: 


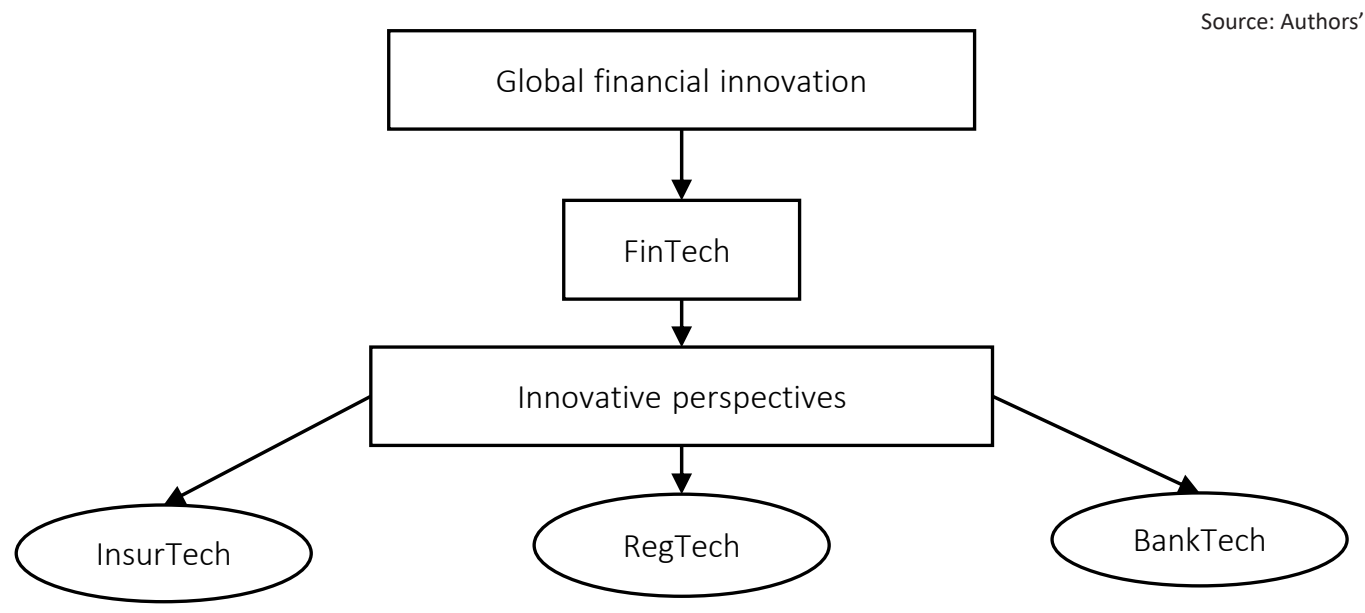

Figure 1. Innovative prospects for global financial innovation

1. InsurTech - the focus of the insurance industry on risk management. InsurTech incorporates innovations from market players who use information solutions for the insurance business.

2. RegTech - a set of regulatory and technological functions in the use of IT for monitoring and reporting.

3. BankTech - technologies and innovations in the banking sector.

Figure 2 presents a matrix model of the transformation of financial innovation. The startup mechanism underlying FinTech's service offerings provides a basis for the development of innovative services, which makes it possible to understand the logic of consumer-oriented startups and therefore belongs to an external organization. RegTech startups focus not only on regulatory compliance but also on identification management, risk management, regulatory reporting, and transaction monitoring. These new business models can be expected to increase regulatory outsourcing, leading to greater digitalization and networking in financial value chains.

The digitalization of retail banking services in the FinTech transformation matrix presented in Figure 2 is at the level of the intersection of the design of external relations with customers and BankTech.

The external organization takes into account the participation of financial institutions in the ecosystem of mobile payments. At the same time, the transformational potential of innovation creates value not only at the firm level but also at the network level, as well as the business logic of InsurTech, as shown in Figure 2.

Analysis of long-term stability of mining with verification of bitcoin performance and value flows between bitcoin network participants refers to the network organization in the BankTech section (Figure 2).

It must be emphasized that decision-making in crowdfunding is different from traditional funding decisions. Therefore, providing an understanding of crowdsourcing processes at the level of network organization makes it possible to apply decision theory to analyze investment decisions in crowdfunding in all three sections: BankTech, InsurTech, and RegTech (Figure 2).

The development of a work advisor for low-budget, risk-averse investors is part of BankTech's internal organization. Based on the theory of IT performance, it is possible to assess how the efficiency of high-frequency securities trading is influenced by traders' trading behavior, market conditions for securities trading, as well as the accuracy of news and their intensity offered to traders. Therefore, the speed of calculations and profitability of high-frequency trading refers to the internal organization of BankTech (Figure 2). Figure 3 shows a matrix of financial innovations.

The impetus for demand will be the predominant determinant of financial innovation that accompa- 


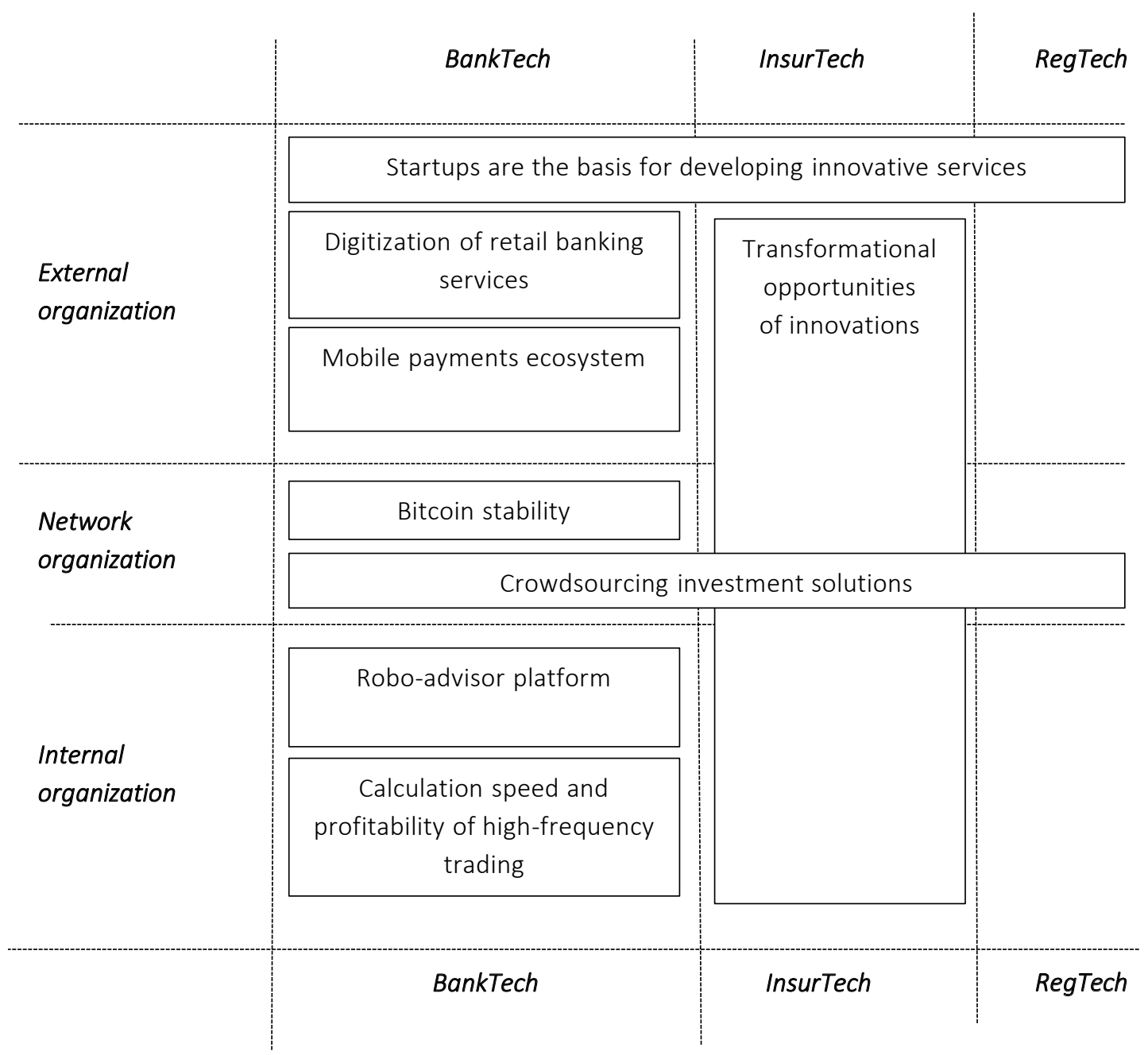

Figure 2. Matrix model of financial innovation transformation

nies evolutionary progress, during which a particular technology is improved and adjusted to meet customer needs. Innovations for the development of financial products can be divided into two main categories: radical and gradual innovations. The division of innovations into supportive and explosive is introduced. It is noted that regulation can lead to destructive innovations, but it can also create obstacles to this. In particular, due to the widespread regulation of financial markets, much of which exists to protect consumers, regulations can sometimes allow transitions to new business models, but can often slow down or prevent such transitions. Thus, antitrust authorities can play an important role, together with other relevant regulators, in protecting regulation, which promotes favorable new competition with due regard to the root causes of financial market regulation, such as prudential considerations and the need to protect consumers.
The main purpose of MODEL 1 is to create a new S-shaped curve for next-generation products using new technologies. However, at the outset, this innovation should be targeted as a product for low-end customers who are not willing to spend more, even at low performance and low quality compared to high-end products in existing financial markets.

This is because, in the initial stages, this innovation is unlikely to be able to meet the requirements of a high-end customer in existing markets. Thus, this is the basic strategy of the innovative MODEL 1.

Thus, the first model of innovation is the most powerful of the four models, as this strategy is designed with the ultimate goal of destroying the product of major financial companies in existing markets after new technologies are developed 


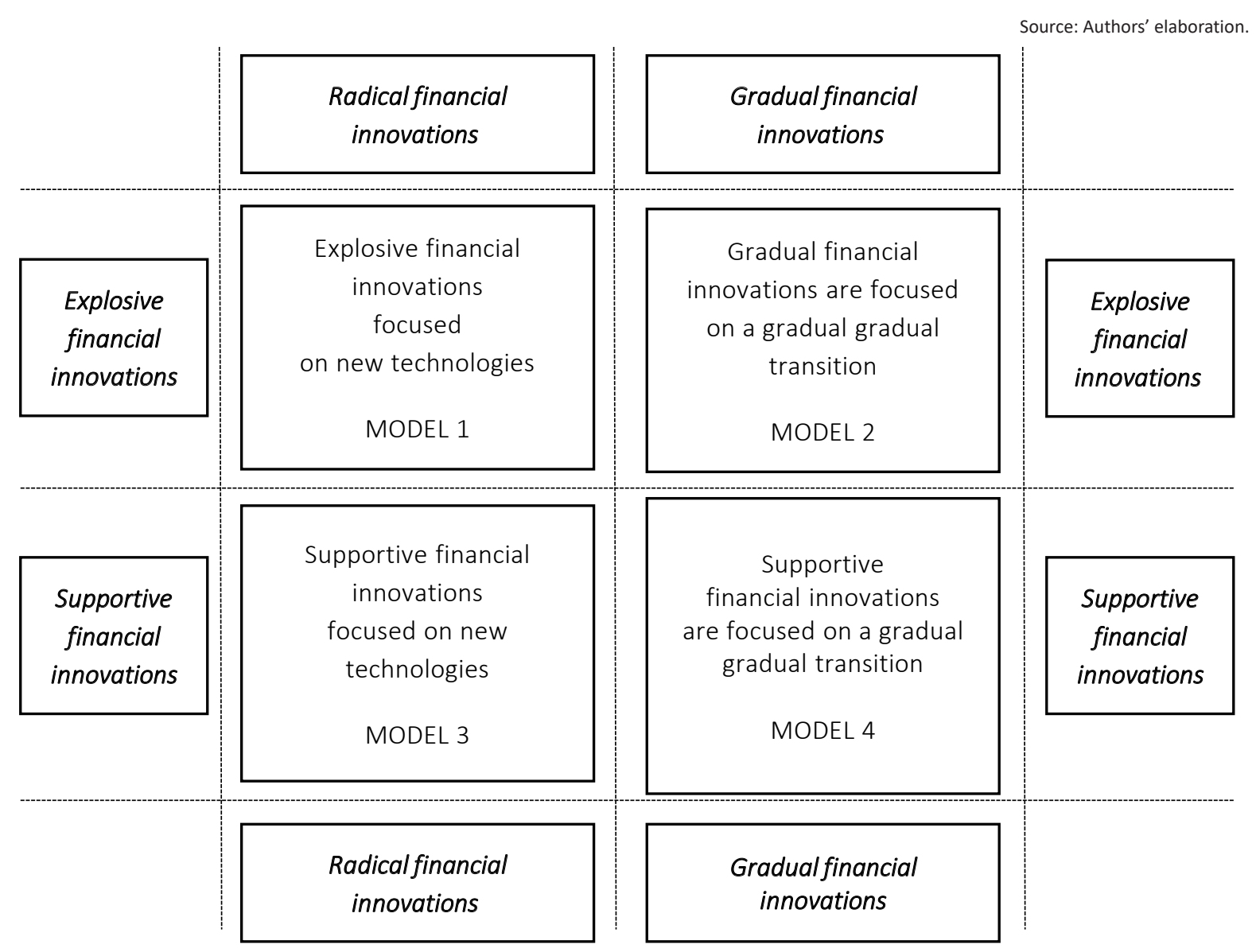

Figure 3. Matrix of financial innovations

(Figure 3). For example, Internet banking makes instant money transfers with messages to customers. The era of daytime transfers is over. Here is another example of MODEL 1: automation of the process of issuing invoices, their payment upon authorization, and tracking the timing of receivables. Elimination of non-automated processes will reduce the number of bank staff, and automatic tracking of receivables leads to a reduction in the time of its collection. Automation of the process of accounting travel expenses in the bank and entertainment expenses, but the costs of the process, as well as the number of staff errors, become minimal.

If the core technologies in MODEL 2 are in the "development" or "ready" stage and have exceeded the requirements of the consumer of financial services, then this innovation actively encourages financial companies to create new financial products. This strategy aims to destroy the products of traditional financial companies produced before these companies focused on innovation. In ad- dition, this innovation is in line with the idea of "existing technologies" in the notion of innovation (Figure 3). For example, the creation of contactless payment cards has encouraged financial companies to create an NFC service from a mobile phone for settlement transactions.

MODEL 3 is based on new financial technologies that create the next $\mathrm{S}$-curve after the key technologies on the previous S-curve become obsolete. Thus, traditional companies in the financial market are developing new technologies that meet the needs of key customers for higher quality (Figure 3).

Figure 4 presents the interpretation of financial innovation matrix models.

The purpose of the strategy interpreted by MODEL 4 is to use the existing basic technologies, comprehensively expanding the existing s-curve. Accordingly, this innovation is based on a detailed understanding of the identified customer requirements, which in- 


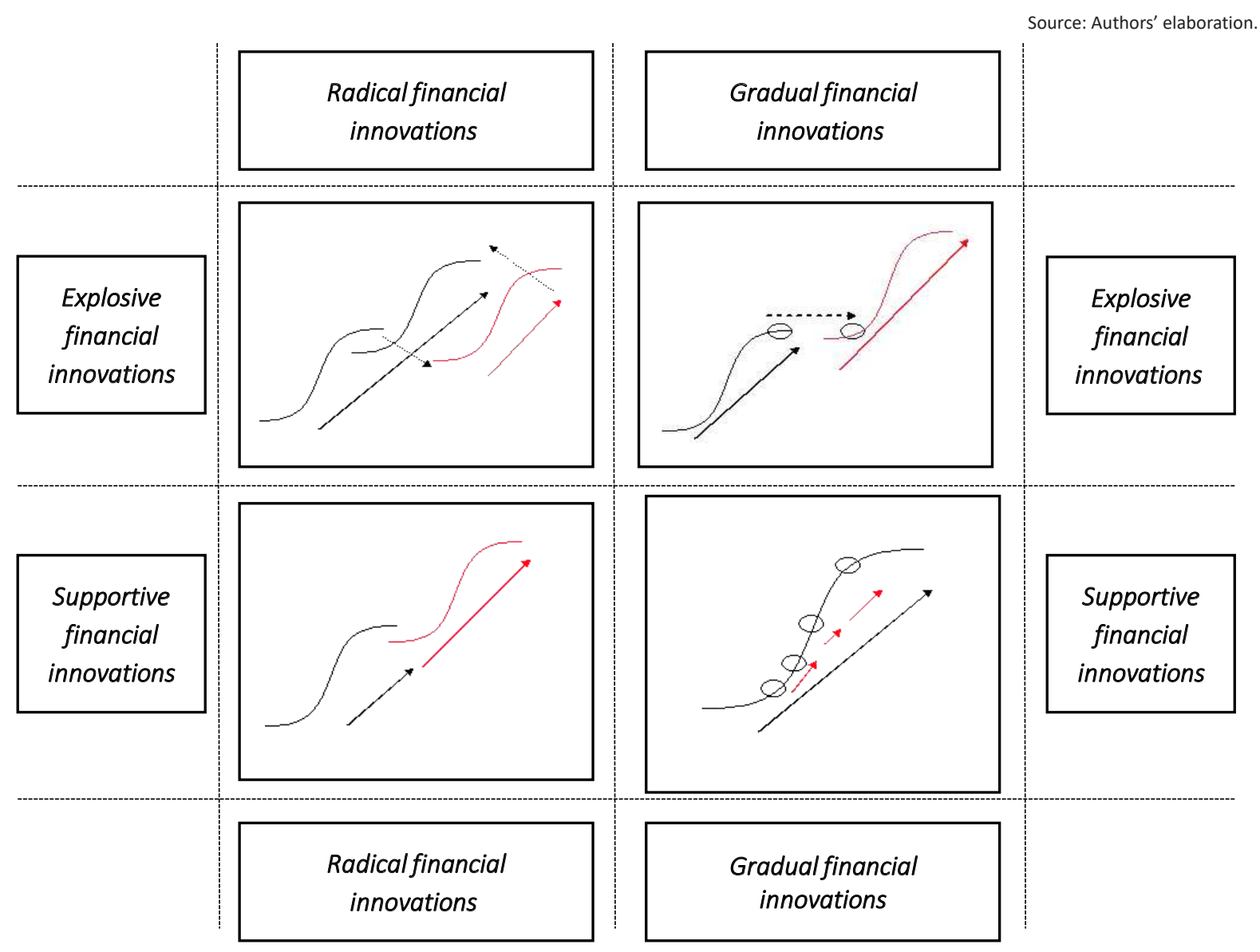

Figure 4. Interpretation of financial innovation matrix models

creases customer satisfaction (Figure 4). For example, the introduction of round-the-clock Internet banking services. The purpose of the strategy interpreted by MODEL 4 is to use the existing basic technologies, comprehensively expanding the existing s-curve. Accordingly, this innovation is based on a detailed understanding of the identified customer requirements, which increases customer satisfaction (Figure 4). For example, the introduction of round-the-clock Internet banking services.

However, each of the models is not independent, it evolves and develops itself, as well as affects other models. Therefore, it is possible to identify prognostic ways of the development of innovative models in their synergy in the form of the movement of two rings, shown in Figure 5.

The prognostic pathway shown in the first circle shows that the innovations run cyclically from MODEL 4 through MODEL 3 and end with MODEL 1. It then returns through MODEL 3 to MODEL 4 (Figure 6). An example is the online provision of financial services using personal computers, tablets, or mobile telephony devices, which has already become the dominant business model in the financial industry.

Further dissemination of e-services and e-payments, including cross-border e-services and e-payments, will include, inter alia, increased processing power of ICT devices and data channels, improved cybersecurity (including wider use of blockchain technology), greater use of digital valet and gadget development.

The prognostic pathway shown in the second circle shows that the innovations go from MODEL 4 to MODEL 2 and continue to cycle. Emphasize that both "innovation pathways" eventually return to MODEL 4 innovation (Figure 7).

An example is the task of financial service providers to develop a deep understanding of their client's needs to determine how best to serve them, which ultimately increases profitability. 


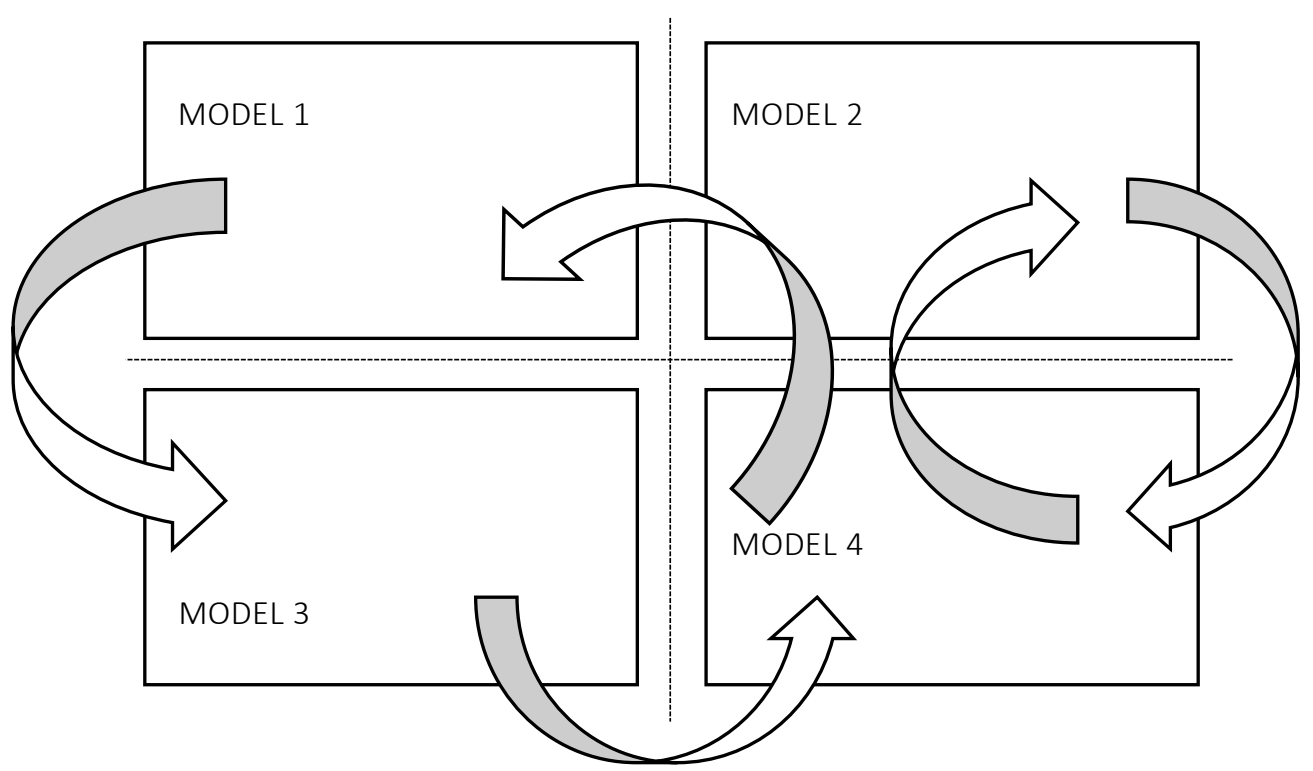

Figure 5. Synergy of prognostic ways of developing innovative models

This leads to the development of digital platforms, which can allow not only a wider distribution of financial services provided by traditional financial institutions but also the promotion of peer-topeer lending and equity financing (crowdfunding) outside traditional financial institutions (MODEL 4). This will expand access to financial services for individuals and businesses, as well as make them less expensive (MODEL 2). Although this may create new risks to financial stability.
Undoubtedly, financial innovations have created a revolution in the financial sector. Today, banks and non-bank financial institutions operate quite differently than they did 20 or 30 years ago. A growing number of customers do not need to physically visit a bank office (or the office of a financial institution) to deposit money, get a loan, make a payment, or transfer or purchase insurance or other financial products. The speed of transactions also increased rapidly. Some traditional fi-

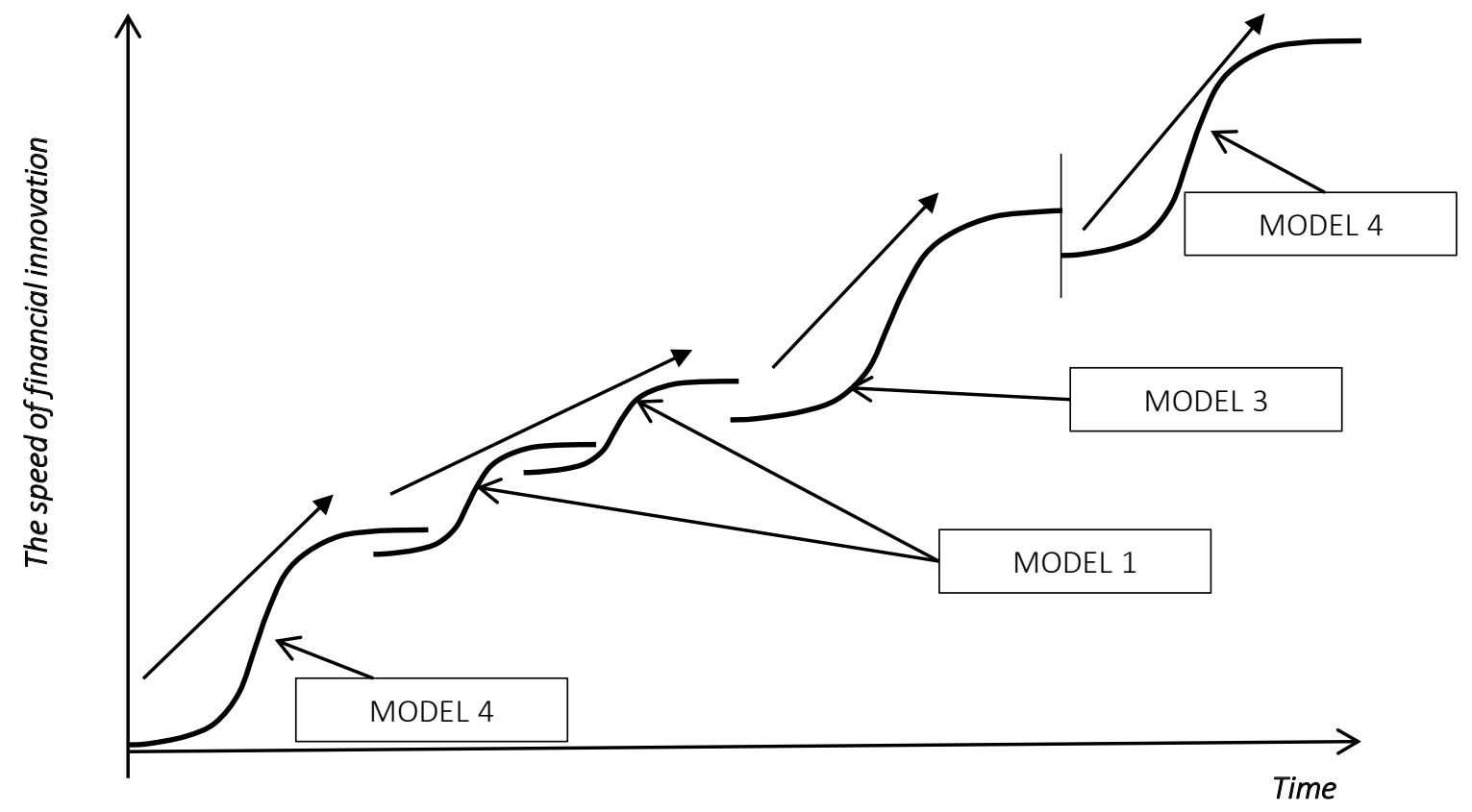

Figure 6. Synergy of innovative models of the first circle of the prognostic path 


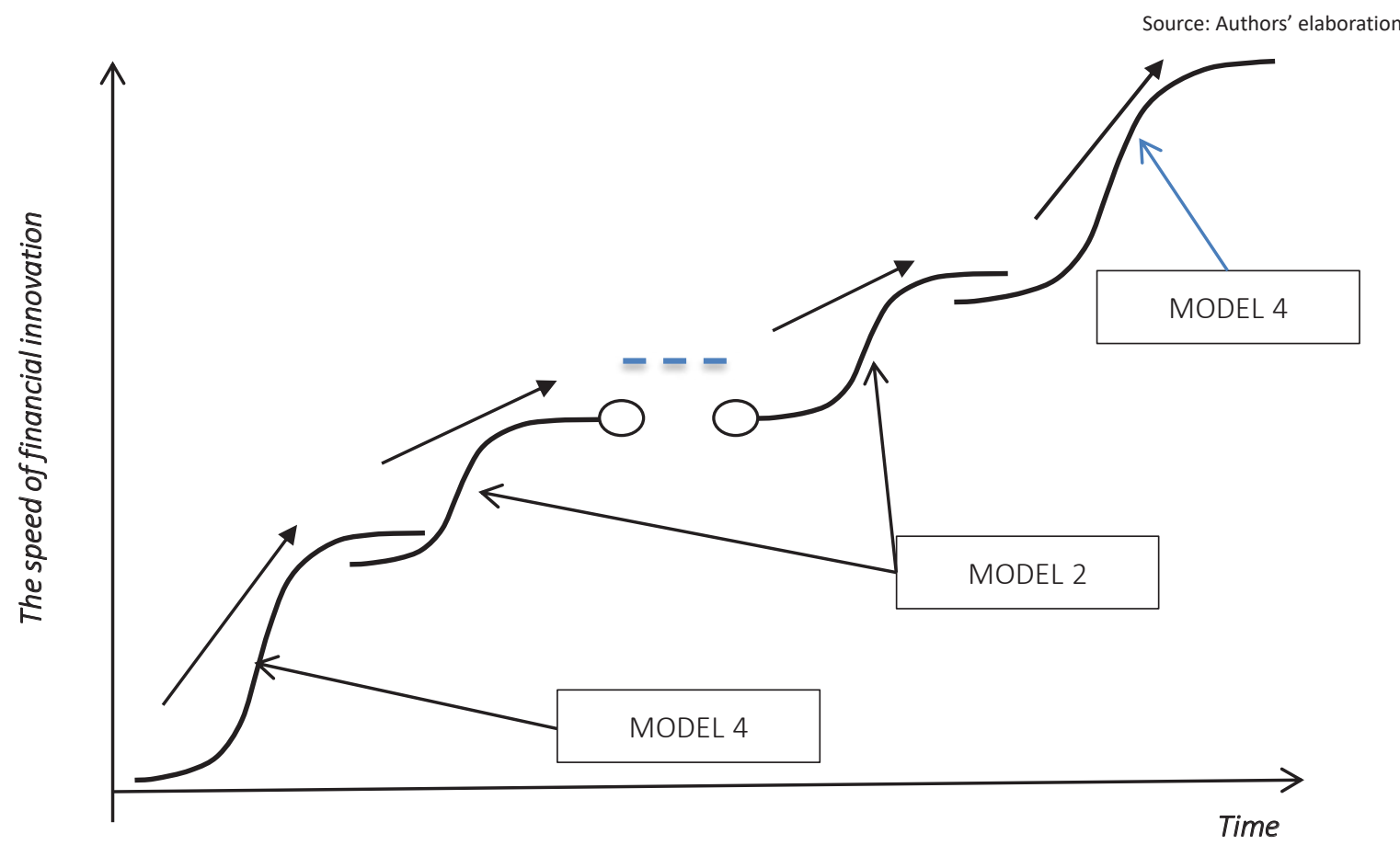

Figure 7. Synergy of innovative models of the second circle of the prognostic path

nancial instruments have either disappeared or their role has diminished dramatically. For example, in many countries, debit cards and electronic transfers have replaced checks. It is easy to imagine that in the coming decades, most financial services will be offered exclusively on the Internet, the operational branches of financial institutions will largely disappear, and various forms of electronic payments and electronic transfers will expand even more. This means significant changes and challenges for traditional business models, as well as the internal organizational structure and employment of all financial market participants.

It can be argued that banks and non-bank financial institutions will not disappear from the market, although their business model may change significantly. Non-financial companies will become technological or information partners of licensed banks and non-bank financial institutions (offering them specific services), and not autonomous financial market players on their own. Thus, digital platforms that offer lending and crowdfunding services or new forms of electronic payments will primarily serve the business operations of licensed banks and non-bank financial institutions a practice that is already followed. Autonomous peer-to-peer lending or crowdfunding platforms will be of secondary importance, operating at the frontier of the financial system concerning small financial redemptions and non-profit activities.

Another issue concerns the chances of modern types of financial institutions to survive from increased competition from other market participants. Potentially non-financial companies, such as ICTs or retailers, can also offer financial services and compete successfully with traditional financial institutions based on their technological advantages. This is already happening (for example, digital platforms or new forms of payment services) and has the potential for rapid expansion. However, how far this will be achieved will depend on the regulatory environment.

\section{DISCUSSION}

Thus, financial innovations offer new opportunities for economic and social development, but at the same time create new challenges and risks, especially in terms of financial stability. Financial innovations had a very limited impact on the formation of monetary policy, which was facilitated by the reduction of financial intermediation after the global financial crisis, which increased the demand for reserve money. Therefore, financial innovations need to be adjusted in various technical 
aspects of central bank operations, such as modifying open market operations and other instruments and updating forecasting models, defining broad monetary aggregates and communication strategies, among others. Financial innovations are rooted in technical and technological changes, regulatory changes, changes in market conditions, and policy changes. The role of regulatory change is ambiguous - financial innovation can be encouraged by both deregulation and tighter regulation. Thus, financial innovation can be defined as the creation of new financial instruments, technologies, institutions, and financial markets. These include institutionality (new types of financial firms), product (new types of derivative or securitized assets), and process (Internet banking, telephone banking, or other forms of application of information and communication technologies).

The pace of financial innovation has accelerated and increased sophistication over the past half century due to rapid economic growth, globalization, financial liberalization, and deregulation, which has contributed not only to the development of new legal instruments and technological progress, especially in information and communication technologies. However, licensed banks and non-bank financial institutions will continue to play a leading role in providing financial services, most likely in partnership with information and communication technologies and data management companies. The use of information and communication technologies does not eliminate the problem of information asymmetry in financial services, which, in turn, requires licensing of financial institutions and regulatory supervision.

Financial innovation, especially the use of information and communication technologies, has already revolutionized the financial sector and will continue to do so in the future. This will bring new products, processes, and organizational and institutional changes. The use of information and communication technologies does not eliminate the problem of information asymmetry in financial services, which, in turn, requires licensing of financial institutions and regulatory supervision. Financial innovation needs to be adjusted in various technical aspects of central bank operations, such as modifying open market operations procedures and other instruments and updating forecasting models, identifying broad monetary aggregates and communication strategies, among others. Financial innovation offers new opportunities for economic and social development, but at the same time creates new challenges and risks, especially in terms of financial stability.

\section{CONCLUSION}

Following the set goal, in determining the imperatives of global financial innovation, the evolution of financial innovations is studied and their classification criteria in the relationship between the financial system and financial innovations are identified. It has been shown that financial innovations offer new opportunities for economic and social development, but at the same time create new challenges and risks, especially in terms of financial stability. Financial innovations are defined as the creation of new financial instruments, technologies, institutions, and financial markets. In the literature review, the signs of competition in FinTech and the characteristics of the level of changes in global transformations in the financial sector were identified. It was found that FinTech's competitive environment includes startups and side participants with a different corporate culture that is different from traditional financial services firms.

In this regard, the innovative perspectives of global financial innovation are considered and a matrix model of financial innovation transformation is presented. This model takes into account the subversive, supportive, radical, and gradual innovations represented by the four models, each of which is not independent, but evolves and develops itself, as well as influences other models.

The results of the study show that in the presented matrix of financial innovations, four innovative models of development are singled out and their synergistic interrelations are proved. These four models of the matrix of financial innovations, which go through cyclically different prognostic paths of devel- 
opment, cause different speeds of financial innovations. This makes it possible to apply the presented models in line with the prognostic ways of developing innovative models in their synergy. Thus, this study indicates the choice of the optimal rate of financial innovation, which requires the development of innovative models and different interpretations of the matrix of financial innovation.

The logistic model of realization of financial innovation function based on nonlinear S-curve is schematically presented. It was found that financial innovations are rooted in technical, technological, and regulatory changes, changes in market conditions, and policy changes. It is shown that the use of information and communication technologies does not eliminate the problem of information asymmetry in financial services, which, in turn, requires licensing of financial institutions and regulatory supervision.

It is concluded that financial innovations, especially the use of information and communication technologies, have revolutionized the financial sector and will continue to do so in the future. This will bring new products and processes and far-reaching organizational and institutional changes.

Summing up, it can be argued that global financial innovation is undergoing significant changes and challenges for traditional business models, as well as the internal organizational structure and employment of all financial market participants. At the same time, innovation imperatives are based on digital platforms that offer lending, crowdfunding, and new forms of electronic payments in the banking sector.

\section{AUTHOR CONTRIBUTIONS}

Conceptualization: Nataliia Savchuk, Tetiana Bludova, Dmytro Leonov, Olena Murashko, Nataliia Shelud'ko.

Data curation: Nataliia Savchuk, Tetiana Bludova, Formal analysis: Nataliia Savchuk, Tetiana Bludova, Funding acquisition: Nataliia Savchuk, Tetiana Bludova, Dmytro Leonov, Olena Murashko, Nataliia Shelud'ko.

Methodology: Tetiana Bludova,

Project administration: Nataliia Savchuk, Tetiana Bludova, Dmytro Leonov, Olena Murashko, Nataliia Shelud'ko.

Resources: Tetiana Bludova, Nataliia Shelud'ko.

Supervision: Nataliia Savchuk, Tetiana Bludova, Dmytro Leonov, Olena Murashko, Nataliia Shelud'ko. Writing - original draft: Nataliia Savchuk, Tetiana Bludova, Dmytro Leonov, Olena Murashko, Nataliia Shelud'ko.

Writing - review \& editing: Nataliia Savchuk, Tetiana Bludova, Dmytro Leonov, Olena Murashko, Nataliia Shelud'ko.

\section{REFERENCES}

1. Arner, D. W., Barberis, J. N., \& Buckley, R. P. (2015). The Evolution of Fintech: A New Post-Crisis Paradigm? (Research Paper No. 2015/047, UNSW Law Research Paper No. 2016-62). University of Hong Kong. http://dx.doi. org/10.2139/ssrn.2676553

2. Bank for International Settlements. (2018). Sound Practices. Implications of fintech developments for banks and bank supervisors. Re- trieved from https://www.bis.org/ bcbs/publ/d431.pdf

3. Barnett, C. (2015, June 9). Trends Show Crowdfunding to Surpass VC in 2016. Forbes. Retrieved from https://www.forbes.com/sites/ chancebarnett/2015/06/09/trendsshow-crowdfunding-to-surpassvc-in-2016/\#2e2f0dc45476

4. Bettinger, A. (1972). FINTECH: A Series of 40 Time Shared Models Used at Manufacturers Hanover
Trust Company. In Interfaces, 2(4) (pp. 62-63). INFORMS. Retrieved from https://www.jstor.org/stable/25058931

5. Bons, R. W. H., Alt, R., Lee, H. G., \& Weber, B. (2012). Banking in the internet and mobile era. Electronic Markets, 22(4), 197-202. https://doi.org/10.1007/s12525012-0110-6

6. Bouwman, H., den Hooff, V., van de Wijngaert, L., \& van Dijk, J. 
(2005). Information and communication technology in organizations: Adoption, implementation, use and effects. Sage Publications. https:// doi.org/10.4135/9781446211519

7. Capgemini. (2017). World FinTech Report 2017. Retrieved from https://www.capgemini.com/wpcontent/uploads/2017/09/world_ fintech_report_2017.pdf

8. CBInsights. (2018). Global Fintech report Q1 2018. Retrieved from https://www.cbinsights.com/ research/report/fintech-trendsq1-2018.

9. Crunchbase. (n.d.). Discover innovative companies and the people behind them. Retrieved from https://www.crunchbase.com/_

10. Davies, S., Jackett, D., Kashyap M., Nicolacakis, D., Qureshi, M. \& Shipman, J. (2016). Customers in the spotlight: How FinTech is reshaping banking - Global FinTech Survey 2016. PricewaterhouseCoopers. Retrieved from https://www. pwc.com/il/he/bankim/assets/fintech-banking.pdf

11. Dhar, V., \& Stein, R. M. (2017). FinTech platforms and strategy integrating trust and automation in finance. Communications of the ACM, 60(10), 32-35. https://doi. org/10.1145/3132726

12. Ehrenfeld, J. (2017). Securities market automation from standards to self-learning machines: Current state and future perspectives. Journal of Securities Operations \& Custody, 9(3), 245-252. Retrieved from http://library.esc. edu/login.aspx? direct=true $\& \mathrm{db}$ $=$ bth \&AN $=124408403 \&$ site $=$ eho st-live

13. Gellrich, T., Hackethal, A., \& Holzhäuser, M. (2005). Vertical integration and bank performance. In O. K. Ferstl, E. J. Sinz, S. Eckert, \& T. Isselhorst (Eds.), Wirtschaftsinformatik 2005 (pp. 547-566). Heidelberg: Physica. Retrieved from https://doi.org/10.1007/37908-1624-8_29

14. Gimpel, H., Rau, D., \& Röglinger, M. (2018). Understanding FinTech start-ups - a taxonomy of consumer-oriented service offerings. Electronic Markets, 28(3),
245-264. https://doi.org/10.1007/ s12525-017-0275-0

15. Gomber, P., Kauffman, R. J., Parker, C., \& Weber, B. W. (2018). On the FinTech revolution: Interpreting the forces of innovation, disruption, and transformation in financial services. Journal of Management Information Systems, 35(1), 220-265. Retrieved from https://doi.org/10.1080/07421222. 2018.1440766

16. Gomber, P., Koch, J.-A., \& Siering, M. (2017). Digital finance and FinTech: Current research and future research directions. Journal of Business Economics, 87(5), 537580. Retrieved from https://doi. org/10.1007/s11573-017-0852-x

17. Goodale, J. (2012). Bank 1.0 and Bank 2.0 success entails learning from each other's best practices (Whitepaper). TSYS. Retrieved from https://digitalpayments.files. wordpress.com/2013/03/bank-10 -and-bank-2-0.pdf

18. Gopalan, S., Jain, G., Kalani, G., \& Tan, J. (2012). Breakthrough IT banking. McKinsey Digital, 26(Spring), 30-35. Retrieved from https://www.mckinsey.com/ business-functions/mckinseydigital/our-insights/breakthroughit-banking

19. Gulamhuseinwala, I., Bull, T., \& Lewis, S. (2015). FinTech is gaining traction and young, high-income users are the early adopters. The Journal of Financial Perspectives, 3(3), 16-23. Retrieved from https://ideas.repec.org/a/ris/ jofipe/0084.html

20. Hornuf, L., \& Schwienbacher, A. (2016). Should Securities Regulation Promote Equity Crowdfunding? SSRN. Retrieved from http:// dx.doi.org/10.2139/ssrn.2412124

21. Lawrence, G. B. (2016). Adaptive financial regulation and RegTech - a concept article on realistic protection for victims of bank failures. Duke Law Journal, 66(3), 567-604. Retrieved from https://scholarship. law.duke.edu/dlj/vol66/iss3/5

22. Lee, I., \& Shin, Y. J. (2018). Fintech: Ecosystem, business models, investment decisions, and challenges. Business Horizons, 61(1),
35-46. https://doi.org/10.1016/j. bushor.2017.09.003

23. Marjanovic, O., \& Murthy, V. (2016). From product-centric to customer-centric services in a financial institution - Exploring the organizational challenges of the transition process. Information Systems Frontiers, 18(3), 479-497. https://doi.org/10.1007/s10796015-9606-x

24. Mcwaters, R. J. (2015). The Future of Financial Services (Final Report). World Economic Forum. Retrieved from http://www3. weforum.org/docs/WEF_The_future_of_financial_services.pdf

25. Michalopoulos, S., Leaven, L., \& Levine, R. (2009). Financial Innovation and Endogenous Growth (Working Paper 15356). National Bureau of Economic Research. Retrieved from http://www.nber. org/papers/w15356.pdf

26. Němcová, Z., \& Dvořák, J. (2013). Technology payment cards communication with banking institutions in the field of cashless payment. Scientific papers of the University of Pardubice. Series D, Faculty of Economics \& Administration, 18(26), 116-128. Retrieved from http://hdl.handle. net/10195/49567

27. Pousttchi, K., \& Dehnert, M (2018). Exploring the digitalization impact on consumer decision making in retail banking. Electronic Markets, 28(3), 265-286. https://doi.org/10.1007/s12525017-0283-0

28. Sawaguchi, M. (2011). Innovation activities based on s-curve analysis and patterns of technical evolution. From the standpoint of engineers, what is innovation? Procedia Engineering, 9, 596-610. https://doi.org/10.1016/j.proeng.2011.03.145

29. Schwab, F., \& Guibaud, S. (2016). The rise of BankTech-the beauty of a hybrid model for banks. In S. Chishti \& J. Barberis (Eds.), The FinTech book (pp. 245-247). Retrieved from https://icpf.ir/ wp-content/uploads/IFP/2018/06/ The-Fintech-Book-finera.pdf

30. Shim, Y., \& Shin, D. (2016). Analyzing China’s fintech industry 
from the perspective of actornetwork theory. Telecommunications Policy, 40(2-3), 168-181. https://doi.org/10.1016/j.telpol.2015.11.005

31. Stan, A.-I. (2018). Computational speed and high-frequency trading profitability: An ecological perspective. Electronic Markets, 28(3), 381-395. https://doi.org/10.1007/ s12525-017-0264-3

32. Stöckli, E., Dremel, C., \& Uebernickel, F. (2018). Exploring characteristics and transformational capabilities of InsurTech innovations to understand insurance value creation in a digital world. Electronic Markets, 28(3), 287-305. http://doi.org/10.1007/s12525018-0304-7

33. Vlastelica, R. (2017, June 6). With bitcoin surge, cryptocurrencies top $\$ 100$ billion in market capitalization. MarketWatch. Retrieved from https://www. marketwatch.com/story/withbitcoin-surge-cryptocurrenciestop-100-billion-in-market-capitalization-2017-06-06

34. Wilson, K., \& Testoni, M. (2014). Improving the role of equity crowdfunding in Europe's capital markets. Bruegel Policy Contribution. Retrieved from http:// bruegel.org/wp-content/uploads/imported/publications/ pc_2014_09_crowd_.pdf_

35. Young, J. (2016, August 1) Without unified, federal regulations for digital currencies, the U.S. Risks falling behind. Bitcoin Magazine. Retrieved from https://bitcoinmagazine. com/business/without-unifiedfederal-regulations-for-digitalcurrencies-the-u-s-risks-fallingbehind- 1470086728 